\title{
Parasitic Infection and the Polarized Th2 Immune Response Can Alter a Vaccine-Induced Immune Response
}

\author{
TARA M. ROBINSON, ${ }^{1}$ ROBIN G. NELSON, ${ }^{2}$ and JEAN D. BOYER ${ }^{1}$
}

\begin{abstract}
The AIDS epidemic in the Developing World represents a major global crisis. It is imperative that we develop an effective vaccine. Vaccines are economically the most efficient means of controlling viral infections. However, the development of a vaccine against HIV-1 has been a formidable task, and in developing countries chronic parasitic infection adds another level of complexity to AIDS vaccine development. Helminthic and protozoan infections, common in developing countries, can result in a constant state of immune activation that is characterized by a dominant Th2 type of cytokine profile, high IgE levels, and eosinophilia. Such an immune profile may have an adverse impact on the efficacy of vaccines, in particular, an HIV-1 vaccine. Indeed, the CD8 cellular immune response and the corresponding Th1 type cytokines that enhance the CD8 cellular immune response are important for clearing many viral infections. It is believed that an antigen specific CD8 cellular immune response will be an important component of an HIV-1 vaccine.
\end{abstract}

\section{INTRODUCTION}

A T THE CLOSE OF THE 20th century, it became increasingly apparent to the scientific and medical communities that Human Immunodeficiency Virus type 1 (HIV-1) was quickly ravaging populations within the developing world. Since its discovery in 1983, the spread of HIV-1 has been growing at an alarming rate. As of the end of 2002, an estimated 42 million people worldwide -38.6 million adults and 3.2 million children younger than 15 years-were living with HIV/AIDS. Approximately $70 \%$ these people (29.4 million) live in Sub-Saharan Africa; another 17\% (7.2 million) live in Asia (UNAIDS. AIDS Epidemic Update, December, 2002). Despite years of research, and the development of pharmaceutical agents in the fight against this disease, there remains no completely effective medical cure or vaccine. While investigating clinical and immunological methods of treatment for HIV-1, researchers have begun to explore other health issues endemic to the developing world, and the impact of these diseases on the morbidity and mortality of the HIV-1-positive native communities.

Parasitic infection and HIV-1 infection coexist in many developing countries, and this is gaining increasing attention. The World Health Organization (WHO) reports that preventable infectious disease is the leading killer of impoverished popula- tions in developing countries throughout the world. They specifically argue for health models that explore the impact of abject poverty and unsanitary living conditions on the health of minority populations throughout the developing world. The WHO states that over 40 million people are severely disfigured and disabled by filariasis, 200 million people are infected by schistosomiasis, and an additional 12 million people are infected with leishmaniasis (World Health Organization, 2000). Chronic parasitic infection is of particular importance due to increasing rates of HIV-1 infection in regions where parasitic infection is also endemic throughout the world. Thus, the need for a thorough examination of parasitic infection and HIV-1 vaccine development is necessary to advance in the fight against HIV/AIDS in both the developed and developing nations. We will explore the complications that arise for developing a vaccine in countries where a high proportion of the population has chronic parasitic infection.

\section{HIV-1 VACCINE DEVELOPMENT: CORRELATES OF PROTECTION}

The mechanism of inducing an immune response through vaccination or antigen presentation is illustrated in Figure 1.

\footnotetext{
${ }^{1}$ University of Pennsylvania, Philadelphia, Pennsylvania.

${ }^{2}$ University of Michigan, Ann Arbor, Michigan.
} 


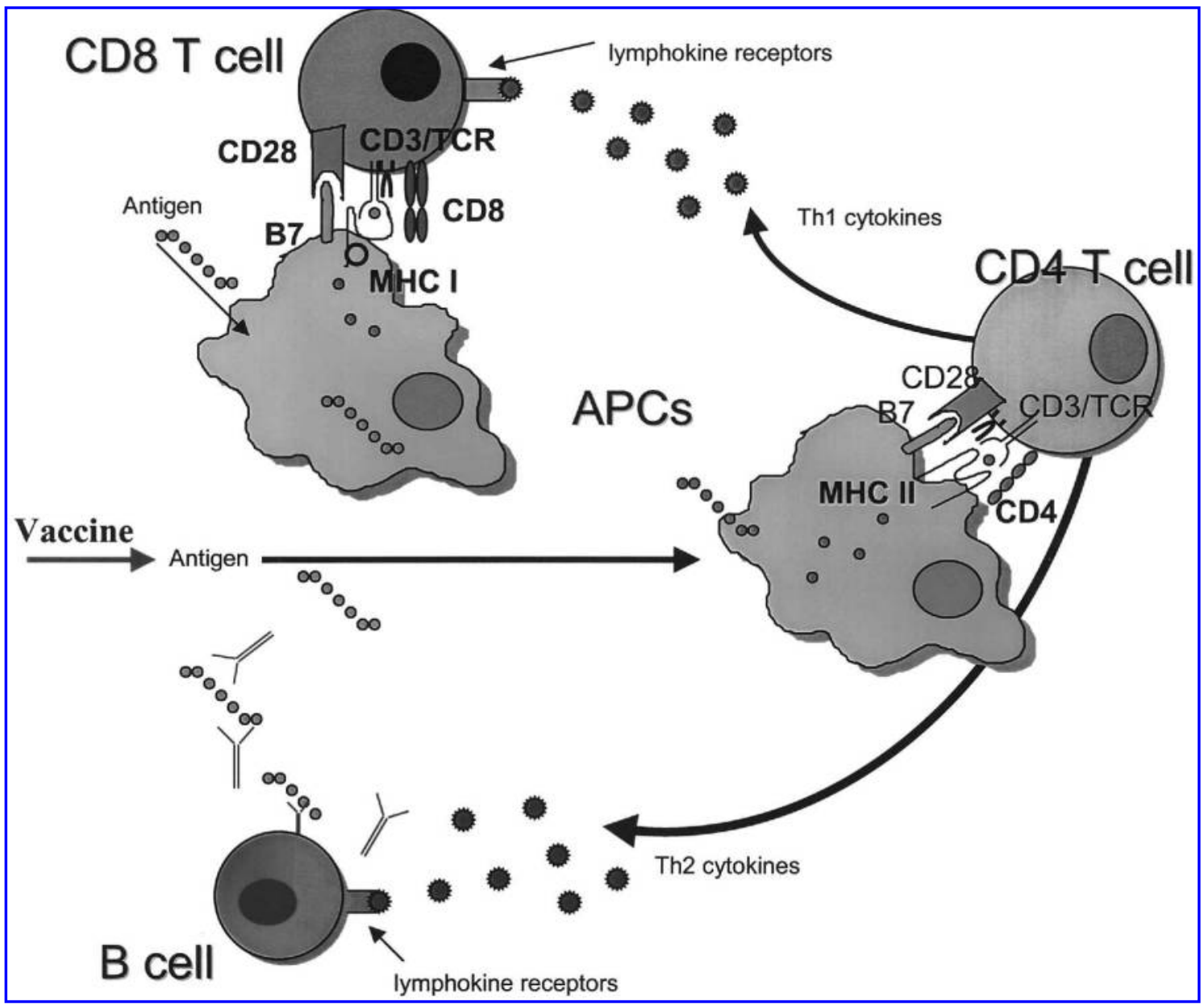

FIG. 1. Antigen presentation to lymphocytes induces an antigen specific immune response. Antigens are presented to the immune system either during infection or by vaccination. CD4 cells are activated through the T-cell receptor binding to peptides presented by MHC class II molecules. CD8 activation occurs through MHC class I presentation. B lymphocytes directly interact through extracellular antigens coming in contact with the $\mathrm{B}$ cell receptor.

Taking an example from history, the most successful vaccine was the smallpox vaccine. This vaccine was a live attenuated vaccine that induced both antibody as well as cellular immune responses. However, because of the nature of HIV-1, insertion and a high rate of mutation, it is likely that no level of attenuation will ever overcome potential safety issues. Yet, in designing a vaccine, a look to what has been observed in persons infected with HIV-1, perhaps individuals who are long-term nonprogressors, may provide clues as to what types of immune responses may limit HIV-1 replication.

\section{The humoral response}

Antibodies are important in preventing susceptible cells from becoming infected by blocking pathogen binding and entry into CD4 cells or macrophages. The humoral arm of the immune system has provided protective responses in several successful viral vaccines. For example, the quantitation of serum neutralizing activity in recipients of polio or influenza vaccines has shown to correlate with the efficacy of the vaccine in preventing disease following later exposure to the pathogen. In addition, vaccines against viral diseases such as rabies and hepati- tis B have produced high-titer neutralizing antibodies, which have been correlated with vaccine efficacy (Hilleman, 1999).

Neutralizing and crossreactive neutralizing antibodies against HIV-1 have been observed in populations of long-term survivors (Cao et al., 1995). Further, higher serological immunity has been observed in mothers who do not transmit infection to their babies (Rossi et al., 1989; Ugen et al., 1992, 1997). It appears neutralizing antibodies are susceptible to the antigenic diversity of the HIV-1 envelope. Therefore, while typespecific neutralizing responses can certainly be protective, there are extremes in the breadth of their protection.

\section{The cellular immune response}

Cytolysis induced by cytotoxic T-lymphocytes (CTLs) has also been shown to correlate with protection in several vaccine models including influenza. Cytotoxic T lymphocytes kill virusinfected cells by recognizing viral fragments expressed on the surface of infected cells associated with the host-specific major histocompatability complex (MHC) class I. Cells that are infected with virus are most likely to be cleared by a specific CTL response. Indeed, a number of anecdotal reports of pre- 
sumed successful protection from HIV-1 infection have shown specific CTL activity. Shearer and colleagues have identified a subset (7 out of 20) of occupationally exposed but uninfected health care workers with evidence of a transient HIV-1 specific CTL response (Pinto et al., 1995). CTLs targeted at particular HIV-1 epitopes were also found in a number of chronically exposed prostitutes who continue to resist infection with HIV-1 (Rowland-Jones et al., 1995). In addition, HIV-1 Gag-specific CTL has been demonstrated in an uninfected perinatally exposed child (Rowland-Jones et al., 1993). Finally, patients mounting strong gp160-specific cytotoxic T-lymphocyte responses have shown a rapid reduction of acute viremia and antigenemia, and a high level of CTL activity has been associated with long-term survival (Borrow et al., 1994; Hulskotte et al., 1995).

There also appears to be a correlation between long-term nonprogression and the ability of lymphocytes from these subjects to proliferate to HIV-1 antigens. In particular, it has been demonstrated that long-term nonprogressors maintain a healthy proliferative response to HIV-1 core protein p24 (Rosenberg et al., 1997; Migueles et al., 2002). This is in contrast to most other HIV infected individuals, in whom the T-cell response to HIV is weak or completely undetectable even at early stages of infection when CD4 numbers are still within normal ranges.

Finally, $\beta$-chemokines were identified by Gallo and colleagues as important contributors to the anti-HIV suppressor activity of CD8 + cells (Cocchi et al., 1995). Levy and colleagues (Mackewicz et al., 1991) performed the initial characterization on HIV-1 suppressor molecules released by CD8+ cells and described two repeatedly exposed but uninfected individuals whose CD4 + cells resisted infection by primary HIV1 isolates and produced elevated levels of the HIV-1 inhibitory $\beta$-chemokines (J.A. Levy et al., 1996).

\section{HIV-1 VACCINE DESIGN: MULTIPLE ANTIGENS, MULTIPLE TARGETS}

Human immunodeficiency virus is an RNA retrovirus belonging to the lentivirus family. The HIV-1 genome is organized into three major structural and enzymatic genes, two regulatory genes, and four accessory genes. Each of these gene products represents possible elements for vaccine exploitation as is detailed below and illustrated in Figure 2.

\section{The envelope}

The viral envelope glycoprotein was the first major vaccine target. The viral envelope binds to CD4 as its first step of in- fection. In 1996, researchers discovered that a second receptor was necessary for the entry of HIV-1 into cells. This molecule was found to be CXCR4, which enables certain strains of HIV1 to fuse with and enter T cells. An analysis of the structure of CXCR4 revealed that it was a receptor for chemokines, the family of signaling molecules that includes beta-chemokines. Shortly following the discovery of the interaction with env and CXCR4 a second chemokine receptor, called CCR5, was discovered that was necessary for the entry of HIV-1 into macrophages. The HIV-1 envelope protein has been included in many vaccine designs. Predominantly, env is considered to be the major target for neutralizing antibody responses. Also, a vaccine modeled after the very successful Hepatitis B vaccine was the first HIV-1 vaccine to be tested in animals and humans. However, it did prove to be effective.

The envelope protein of HIV-1 is the most heterogeneous of all viral proteins. Also, it may be necessary to include several envelopes into a single vaccine. In fact, one of the obstacles to developing a vaccine against HIV-1 is the high mutation rate of the virus. In fact, it is common for several different variants of the virus to live within one individual. The high mutation rate is caused by the fact that the reverse transcriptase lacks a proofing function. The mutation rate is estimated to be one error per round of replication. Over time, the virus has mutated to create thousands of strains that exist around the globe. These strains can be categorized into several different clades or subtypes, designated A through G. A global vaccine for HIV-1 will need to be crossreactive. Yet, the possibility of continued mutations to the viral sequence could lead to immune escape.

It is possible that including as many of the viral genes as possible in a vaccine could combat the sequence variation that is observed. In a manner that is similar to highly active antiretroviral treatment (HAART); if a vaccine can combat the virus by attacking multiple components, immune escape can possibly be overcome. However, this can only be accomplished by inducing a cellular immune response since the envelope is the only protein available to antibody binding.

\section{The viral core}

Within the envelope of a mature HIV-1 particle is the capsid, made of 2000 copies of $\mathrm{p} 24$. The capsid surrounds two single strands of HIV RNA, each of which has a copy of the virus's nine genes. The core of HIV-1 also includes p7, the HIV-1 nucleocapsid protein; and p17, or the HIV matrix protein, which lies between the viral core and the viral envelope. These core HIV-1 proteins have been included in vaccines predominantly to induce a cellular immune response against the virus.

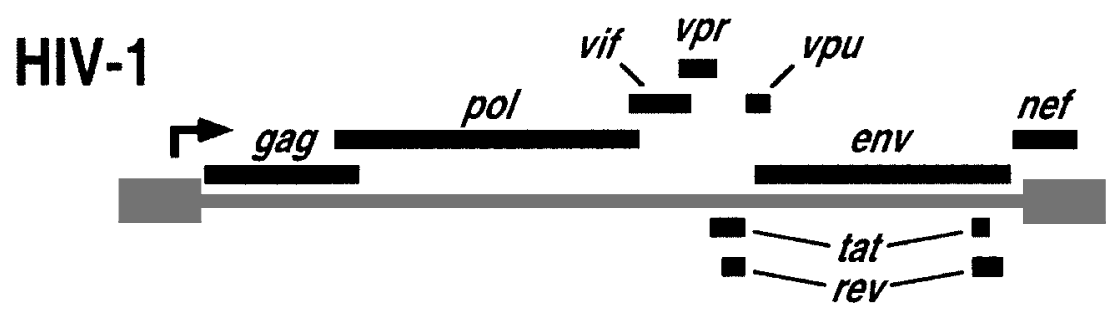

FIG. 2. HIV-1 viral genome. Each component of the HIV-1 genome is a potential target for the immune system. 
Following the entry of the virion into the cell the synthesis of the DNA provirus, a double-stranded DNA version of the HIV-1 genome, is completed by the viral DNA polymerase and reverse transcriptase (RT). The DNA provirus is then translocated into the nucleus as a component of the proteinDNA-preintegrationcomplex, where the viral integrase enzyme (INT) aids in its incorporation into the host cell genome. After integration, the DNA provirus replicates with the host cell DNA every time the cell divides. These genes are now being included in current vaccine design.

\section{The regulatory genes}

The regulatory genes tat and rev affect HIV-1 gene expression. However, tat transactivation has been shown to increase viral replication in host cells several 100-fold, and may need to be eliminated from or certainly attenuated within a potential vaccine. The rev protein, through its interaction with the Revresponse element (RRE), increases the number of unspliced RNAs from the nucleus by its displacement of host splicing factors which would prevent RNA transport from the nucleus to the cytoplasm. Rev also plays a major role in the production of structural proteins of HIV-1; therefore immune responses directed against the rev gene itself could serve to effectively interfere with the viral life cycle (Cullen and Greene, 1990). Additionally, the fact that rev is produced early suggests that immune responses targeting here could be especially important as well as to those targeted against nef.

\section{The accessory genes}

The accessory genes (vif, vpr, vpu, and nef) serve as potential targets for vaccination as well. These four gene products are termed "accessory" because of the fact that upon their deletion from the HIV-1 genome, in vitro viral replication remains intact. The vif (viral infectivity factor) protein, which is located in the plasma membrane, is important for the production of infectious virions in certain cells (Rosen, 1991). Experiments using vif mutants elucidated the necessity of vif expression for viral infectivity of peripheral blood mononuclear cells and macrophages (Fan and Peden, 1992). Vpu (viral protein u) plays a role in the downregulation of $\mathrm{CD}^{+}$cells and the increase of viral transcription (Klimkait et al., 1990). The $v p r$ (viral protein $r$ ) protein plays several roles including increasing viral replication, arresting host cell division, and reactivating virus from a latent phase (D.N. Levy et al., 1993, 1994a, 1994b). While nef (negative factor) has not been shown to play a critical role in viral infection of cell lines in vitro (Kim et al., 1989), experiments conducted with the related simian immunodeficiency virus have shown a decrease in viral replication in rhesus macaques infected with virus with a deletion in the nef gene (Kestler et al., 1991). More importantly, throughout the followup examination, there was evidence of decreased pathogenesis of SIV infection observed. This observation was in sharp contrast to animals infected with either wild-type nef or virus containing a stop codon within the nef gene. These later animals produced significantly higher levels of virus, where 5 out of 12 subsequently developed immunodeficiency and died. Finally, nef appears to provide an important target for cytotoxic T-lymphocyte activity.

\section{HIV-1 VACCINES IN DEVELOPMENT}

At the beginning of the AIDS epidemic, the vaccine against hepatitis B proved to be very successful. Given that at that time there was no cure or even good treatment options for infected individuals along with the recent success of the protein based hepatitis $B$ vaccine, it seemed that a protein vaccine would be the safest and best choice for an HIV vaccine. Several groups have reported on the use of recombinant gp120 and gp160, the envelope protein of HIV. All studies have shown that the protein is well tolerated and safe, but the immune responses generated by these vaccines are generally not thought to be of a protective level (Sitz et al., 1999; McCormack et al., 2000; Cunningham et al., 2001). Protein vaccines drive the immune response towards the Th2 cellular response and generation of antibodies. However, it has proven very difficult to raise antibodies against gp 120 because of the high levels of glycosylation and the CD4/gp120 binding site and the coreceptor binding sites which are deeply recessed and hidden by the V3 loop, respectively (Kwong et al., 1998).

The 1999 study by Sitz et al. tested recombinant gp160 and recombinant gp120 in both low-risk uninfected patients and well as infected individuals. Although the vaccine posed no threat to safety, it elicited only weak responses to a small number of peptides, and no patients responded to the whole gp120 protein (McCormack et al., 2000). Another study by Nitayaphan et al. (2000) showed that immunization with $50 \mu \mathrm{g}$ of rgp120 at months 0,1 , and 4 or 0,1 , and 6 elicited no more adverse reactions than placebo, and 39 of 52 subjects developed neutralizing antibodies to the homologous $\mathrm{HIV}_{\mathrm{SF} 2}$ strain. Twenty-two subjects also developed neutralizing antibodies against the heterologous strain $\mathrm{HIV}_{\mathrm{MN}}$, a laboratory adapted strain of the virus. However, recent studies have shown that although HIV infected patients develop neutralizing antibodies against autologous virus, the rate of their production lags behind the mutation rate of the virus (Wei et al., 2003). This group showed that neutralizing antibodies can neutralize virus isolated from previous timepoints, but they cannot neutralize virus that is isolated at the same time as the neutralizing antibodies.

Protein vaccines have been tested in both the United States and Thailand, and have progressed to Phase III clinical trials. However, there is increasing concern about their efficacy, as the trials did not conclusively prove to lower the rate of infection in HIV negative vaccine recipients (Francis et al., 2003). Unfortunately, current hope for these vaccines is not high.

The generally low cellular immune responses generated by protein and peptide-based vaccines have driven investigators to find adjuvants to enhance the immune response. Several groups have reported on the use of aluminum hydroxide (alum) as an adjuvant for both recombinant protein and peptide vaccines. None of these studies showed serious adverse events with alum, including a study where infants born to HIV-infected mothers were given doses up to $300 \mathrm{mg}$ rgp120 with alum adjuvant (McCormack et al., 2000; Cunningham et al., 2001; Lambert et al., 2001). However, alum did not prove to dramatically increase the immune response. However, not all vaccines and adjuvants tested have been so innocuous. Toledo et al. (2001) tested TAB9, a multiepitope vaccine comprising elements of the V3 loop from six HIV-1 isolates that was emulsified in Montanide 120. Twenty-four healthy, low-risk HIV-1 seronegative adult males received three immunizations of $0,0.2$, or $1 \mathrm{mg}$ at 0,1 , 
and 6 months. At the lowest dose group, seven out of eight recipients experienced severe or local inflammation, and four out of eight recipients in the higher dose group experienced granulomas and sterile abscesses. Although there were some safety issues, the vaccine was immunogenic. All participants in the vaccine groups produced antibodies that were broadly reactive against peptides from the MN and IIIB strains, and 50\% of subjects were able to neutralize at least one of the five laboratory isolates tested. The group also observed lymphoproliferation, with the response being stronger in the higher dose group.

\section{Canarypox}

Recombinant canarypox are some of the first and most exhaustively tested live recombinant vectors tested in human clinical trials. Canarypox vectors include most of the HIV-1 genes/epitopes and have lead to cellular immune responses in volunteers. Indeed, these HIV-1 specific CD8 cells were able to kill peripheral blood mononuclear cells infected with primary isolates of HIV-1 (Ferrari et al., 1997), and were able to kill cells infected with HIV from other clades.

\section{DNA vaccines}

Another approach to vaccination that has gone to the clinic is to immunize with plasmid DNA-encoding HIV antigens. As discussed previously, DNA vaccines are a particularly appealing strategy for HIV because of their safety, low cost of preparation and storage, and ease of administration. After establishing safety and immunogenicity in primate models, a DNA vaccine engineered in our lab was evaluated in a Phase I clinical trial of asymptomatic HIV-infected patients who were not on antiretroviral therapy (MacGregor et al., 1998). The study included three groups of patients who were administered three doses of 30,100 , or $300 \mu \mathrm{g}$ of plasmid DNA encoding the env/rev genes. These immunizations were given intramuscularly. The vaccine was well tolerated in all groups, and antibody titers against gp120 were increased in the 100 and 300$\mu \mathrm{g}$ groups. Individual patients also demonstrated increases in CTL activity and lymphoproliferation Following these positive results, the vaccine was then tested in HIV-negative volunteers (Boyer et al., 2000). These subjects received four doses of vaccine at either the 100 or $300-\mu \mathrm{g}$ dose level. In the higher dose group, six out of six patients demonstrated antigen-specific lymphoproliferation and production of interferon- $\gamma$ and $\beta$ chemokines. These responses varied by individual and also at different timepoints in the study.

After the initial success of the first clinical trials of DNA vaccines, several labs have developed unique strategies to capitalize on the fact that plasmid DNA generally drives a Th1-biased immune response, generally considered crucial for an effective vaccine. Several labs, including our collaborators, have sought to codon-optimize DNA vaccines to enhance the cellular immune response. As described by Qiu et al. (1999), several point mutations have been made to enhance the secretion of the gag protein that is translated after transfection in the host. Harriet Robinson's group has developed a plasmid that encodes for SIV gag, pol, vif, vpr, and vpx, as well as HIV env, tat, and rev from a single transcript in the hopes of boosting the immune response by giving many different antigenic targets (Amara et al., 2002).
Currently, there are several groups that are trying to maximize the level of immune responses by first priming with DNA, then boosting with a live vector. Several live vector expression systems have been tested in the context of HIV and SIV. These vectors have been engineered to include various parts of the HIV genome. This system is attractive because the live vector allows for the antigen to be presented via the MHC-1 pathway. Vectors can also be modified so they are replication defective in the host, thus increasing the safety of this type of vaccine.

\section{Prime-boost strategies}

There have been several studies that have tested recombinant canary pox vectors in combination with DNA or recombinant protein. The first large-scale prime-boost study using this vector was done by Belshe et al. (1998), who reported on the use of ALVAC vCP205 (Pasteur-Meriaux) as the priming vaccine. This vaccine is a canary pox vector expression gp120, p55, and protease. Four hundred thirty-five volunteers, both low- and high-risk individuals, received four doses at $0,1,3$, and 6 months. A control group received no boost, and the experimental group received a boost of recombinant gp120. Neutralizing antibodies to the MN strain were stimulated in $94 \%$ of the volunteers given vCP205 and gp120 and in 56\% of volunteers given vCP205 alone. CTL responses in this study were intermittent, with $33 \%$ of the volunteers in either group responding at some time point during this study. This study was very promising, as the results of the prime-boost regimen proved to be superior to either vaccine given alone.

Bures et al. (2000) reported on a study where patients were given one of three different canary pox expression vector coding for the membrane anchored region of HIV-1 ${ }_{\text {MN }}$ gp120 followed by a boost with a soluble gp160 hybrid consisting of MNgp120 and the majority of gp41 from HIV-1 ${ }_{\text {IIIB }}$. This study mainly focused on the elicitation of neutralizing antibodies. They found that the majority of neutralizing antibodies were specific for the MN-V3 loop, and that despite MN-specific neutralization titers exceeding 1:500 at some timepoints, no neutralization of primary isolates was detected. Little to no neutralization of HIV-1 $1_{\text {IIIB }}$ heterologous lab adapted strains was detected.

In early 2002, the NIAID decided not to proceed with Phase III trials of the combination of ALVAC, a canarypox vector containing env antigens, and AIDSVAX, a gp120 protein based vaccine (HVTN 2002). This decision was based on results of earlier trials that showed that the production of interferon gamma, which is considered to be a partial correlate of protection, was very low as detected by ELISpot. ELISpot is a very sensitive assay that can detect a frequency as low as one in $1 \times$ $10^{6}$ cells producing IFN- $\gamma$ after antigen-specific stimulation.

There are several prime-boost combinations that are still in macaque trials that have shown good results thus far, and provide hope that these results can be duplicated in humans. Merck has done a study in which rhesus macaques were given either plasmid DNA encoding the SIV gag gene alone, DNA with a modified vaccinia Ankara (MVA) boost, and DNA with a recombinant adenovirus (Ad5) boost (Shiver et al., 2002). Some animals also received an adjuvant known as CRL1005, a nonionic blocked copolymer adjuvant, or alum-however, the mag- 
nitude of this effect was not as great as the effect of the primeboost regimen. They observed that the animals that received the Ad5 generated the highest immune responses as measured by levels of circulating antigen-specific $\mathrm{CD} 8^{+} \mathrm{T}$-cells and control of infection after SHIV challenge. However, while the initial results of the trial were very promising, the group has recently reported that several of the macaques in the trial have experienced breakthroughs in viral load more than 1 year after the challenge (10th Conference on Retroviruses and Opportunistic Infection, Boston, MA, 2003).

As alluded to previously, Harriet Robinson's group has completed a trial in macaques to evaluate the DNA plasmid encoding the SIV genes gag, pol, vif, vpr, and vpx as well as HIV env, tat, and rev in a single expression vector along with an MVA boost (Amara et al., 2002). The MVA was recombinant for SIV gag and pol and HIV env under the control of vaccinia virus promoters. Animals were given DNA at weeks 0 and 8, boosted with MVA at week 24, and challenged with SHIV 89.6 7 months after the boost. Interestingly, the group showed that while route of administration did not have a significant effect of the cellular response, animals receiving DNA intradermally had a 10-fold higher level of antibody production. Two weeks after the challenge, animals that received the prime and boost demonstrated at least a one log difference in viral load, and have since been able to control viral replication to very low levels.

As of yet, there are no vaccines that appear to be able to induce an effective response against HIV-1. However, it has become clear that a Th1 CD4 response and the corresponding CD8 response will be important to suppressing HIV-1 infection. It is believed that IL-4 and IFN- $\gamma$ are directly in competition and IL-4 has a negative impact on the CD8 immune response.

\section{PARASITIC INFECTION AND HIV-1 VACCINE DEVELOPMENT}

Helminth infections are characterized by highly polarized Th2 cytokine responses. They have been shown to modulate the immune responses to nonparasite or heterologous antigens by suppression of Th1 cytokines production and enhancing Th2 cytokine secretion in experimental animal models. In fact, suppression of IFN- $\gamma$ to tetanus toxoid following tetanus vaccination has been shown to occur in humans infected with $\mathrm{On}$ chocera volvulus and Schistosoma mansoni (Sabin, et al., 1996; Rowe et al., 2000). Such a phenomenon could bias the effectiveness of any vaccine not only by affecting the induction of IFN- $\gamma$ but also by altering the function of CD8 cells (Fig. 3).

Berzofsky and colleagues were the first to test this hypothesis in the mouse model. Utilizing $S$. manosi, they infected $\mathrm{Balb} / \mathrm{c}$ mice and demonstrated that a biased Th1 response could lead to a down regulation of functional CTL following vaccinia vaccination (Actor et al., 1993). More recently, Bot demonstrated the impact of IL-4 on CD8 responses. Using a transgenic mouse which expresses IL-4 under a lung specific promoter, Bot found that infiltration of CD8 cells into the lungs was decreased when the transgenic mice were challenged with influenza (Bot et al., 2000). The ability of the mice to clear heterologous infection was delayed. Importantly, the CD8 response, however, was not completely abrogated. Indeed, we have observed in an L. major infection model the number of vaccine-induced antigen-specific CD8 cells that are able to secrete IFN- $\gamma$ is reduced in the parasitically infected mice (Boyer et al., unpublished results). The most simplistic view is that IL4 inhibits the production of Th1 type cytokines, and therefore, the development of a CD8 cellular immune response.

\section{PARASITIC INFECTION}

Fontanet et al. (2000) conducted an epidemiological study of parasitic disease and HIV infection among sugar-estate residents in Ethiopia. Not surprisingly, this study revealed that $70.1 \%$ of the inhabitants had at least one parasitic infection and, between 3-5\% of the workers were HIV seropositive. They concluded that HIV seropositive patients had an increased risk of amoebic infection as a result of chronic immunosuppression. A similar study conducted by Wiwanitkit explored the presence of intestinal parasites among HIV positive patients in Thailand (Wiwanitkit, 2001). This study concluded that opportunistic parasitic infections showed the highest prevalence among patients with CD4 counts below 200/ $\mu$ l. Each of these studies reflects the need for increased research in the field of parasitic and HIV coinfection, and moreover, the need to examine these diseases in relationship to the community and the available public health resources.

\section{The biology}

Parasites within the genera Trypanosoma, Leishmania, and Schistosomiasis are prevalent throughout Africa and some parts of Asia, and consequently, have severely hindered medical interventions for both HIV-positive and -negative populations. Trypanosoma is caused by hemoflagellates belonging to the complex Trypanosoma genus and two morphologically undistinguishable subspecies of Trypanosoma brucei, which cause distinct disease patterns in humans (CDC, 2001). Within the medical community, Trypanosoma is widely recognized as the cause of various forms of African Sleeping Sickness, a disease that a results in fever and flu-like symptoms, and eventual involvement of the central nervous system. This parasite is transmitted by the tsetse flies of the genus Glossina, as they take a blood meal on infected mammals (CDC, 2001). These parasites undergo several stages of growth, and development within the salivary glands and gut of the host fly, and then are transmitted to another host mammal through an insect bite. Metacyclic trypanosomes are inoculated, and subsequently, they multiply in the host's blood and extracellular fluids including spinal fluid. Like other parasites, infection with Trypanosoma results in chronic immune activation, and thus hinders the body's ability to counteract any further infection, including HIV.

Leishmania is another parasite that is attracting increasing attention from the medical community due to its prevalence in developing countries. There are many forms of Leishmania, including cutaneous and visceral. The WHO has reported that there is alarm at the sharp increase in cases of visceral leishmaniasis, a deadly form of the disease (as opposed to the less pathogenic cutaneous form) due to coinfections with HIV (WHO, 2000). This parasite is transmitted by the bite of female phlebotomine sandflies (CDC, 2001). Like Trypanosomes, 


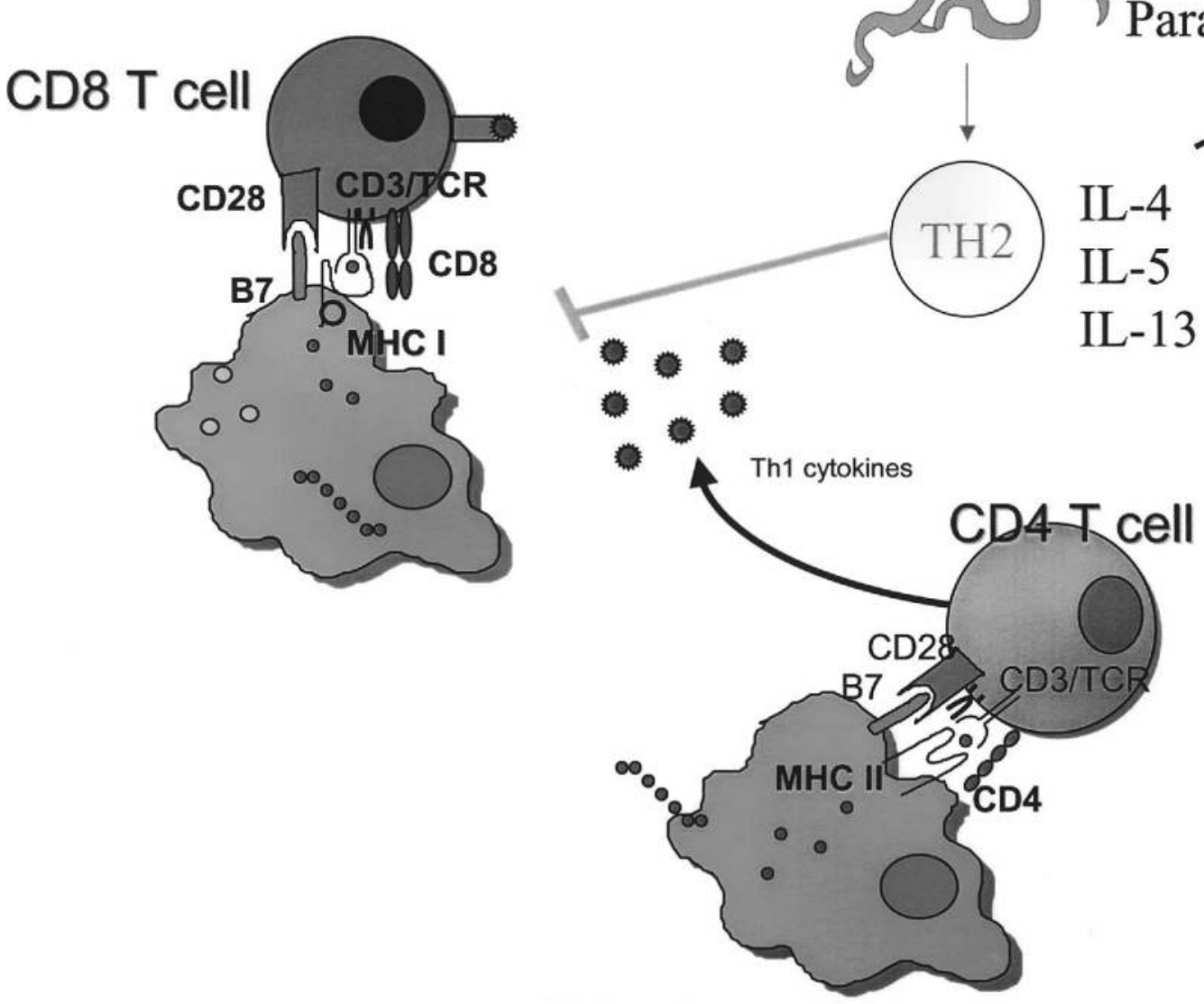

FIG. 3. Parasites induce a Th2 polarized immune response. The immune activation observed during parasite infection includes increased production of IL-4. IL-4 can directly inhibit the production of IFN- $\gamma$ and reduce the desired Th1 and CD8 cellular immune response to various vaccines including HIV-1.

these flies become infected following a blood meal on an infected host, and within the sandflies, the parasites differentiate into promastigotes that mature and multiply. The fly regurgitates these promastigotes during the subsequent blood meal on the next host, and the promastigotes that reach the puncture wound are phagocytized by macrophages, where they reside (CDC, 2001). Leishmania infection is characterized by internal organ damage, skin lesions, and mutilation of the nose and mouth. Certain strains of this parasite are not able to be cleared by the immune system and reside in the macrophages for the lifetime of the infected individual.

Schistosomiasis is caused by digenetic blood trematodes, and thus, is primarily transmitted through multiple uses of unsanitary waterways. Dessein et al. (2001) state that following penetration of the skin by the free-swimming larvae, Schistosomes live in the blood of the human host either in the mesenteric veins or in the vesical plexus. Chronic infection is caused by eggs that are trapped in tissue of the urinary tract or in the liver. In patients that are unable to overcome the initial scarring that results from inflammation, fibrotic tissue may accumulate around the eggs and in the portal spaces, which can cause obstruction of the blood flow in the portal system. These patients may die of hypertension, varices, coinfection, or heart failure. These studies show that Trypanosoma, Leishmania and chronic Schistosomiasis infection have severe biological ramifications that are only complicated further by HIV/AIDS coinfection.

\section{The immune response}

An examination of the impact of parasitic infection on the developing world is of increasing importance due to the immunological impact of these chronic diseases on the body's immune system, and thus, the body's ability to counter additional infectious diseases, specifically HIV. An investigation of the immunological record of helminth parasites reveals that infection is accumulative and chronic, and immunity is rare in most cases (Allen and Maizels, 1996). Thus, many patients succumb to rapid reinfection following drug treatment. It has been shown, however, that immunity does aid in limiting the extent of infection, with adults becoming less likely to be reinfected than children. This is particularly true among patients suffering from infection with Schistosomiasis. Many studies investigating parasitic infection, immunity, and vaccines have centered on the role of T-cell subsets and cytokine production. 
Th1/Th2 polarization is most striking in parasitic infection, and reflects a complex results in the induction of Th2 cell subsets within the murine model. Researchers have demonstrated that helminthic infection results in the induction of Th2 cell subsets within the murine model. This is illustrated by the upregulation of interleukin IL-4 and the subsequent down regulation of IFN- $\gamma$. Sher et al. have explored the role of macrophages in response to cutaneous leishmaniasis in nonvaccinated, infected BALB/c mice (Scott, 1983). They determined that the selective induction of the Th2 cytokines in this inbred strain results in suppression of macrophage-mediated clearance of the parasite. Sher et al. cite a Mosmann and Moore study (1991), which demonstrated that the Th1/Th2 imbalance induced in schistosomiasis can be interpreted as the manifestation of cytokine crossregulation. Th1 cytokines are defective due to their inability to differentiate. This results from the upregulation of IL-4 synthesis. In addition, IL- 10 acts to inhibit IFN- $\gamma$ by blocking the production of the TNF-alpha triggering signal, resulting in the inhibition of the NO effector pathway for parasite killing. The studies of Pearce et al. (1991), Gazzinelli et al. (Sher et al., 1992), and Heinzel et al. (1991) support Sher's argument that parasitic infection is characterized by the downregulation of cell mediated immunity, and the upregulation of inhibitory cytokines IL-10 and IL-4. Parasitic infection within the murine model has presented a clear illustration of the crossregulation of cytokines, and the delineation between Th1 and Th2 cell subsets in response to infection.

Having examined the murine model, it is necessary to examine the current human clinical research. Studies conducted by Butterworth (Capron et al., 1984) and Hagan (de Andres et al., 1997) and reviewed by Allen and Maizels reveal that the most effective immune combination to combat chronic parasitic infection is IgE and eosinophils. Although these cells are noneffector T cells and derive from Th2-mediated mechanisms, they have been shown to contribute to the reduction of parasitic load. Allen and Maizels state that mast cells in the mucosa generate physiological changes in the gut that lead to worm expulsion through the release of a large battery of biologically active mediators. Moreover, they state that surface-bound IgE, and the increased plasma levels of IgE following infection possible serve to focus mast-cell mediator release against parasites. Thus, although it is evident that the immune system has developed methods to control parasitic infection, the inability of the body to develop a primary Th1 immune response to infection has resulted in chronic and fatal infection, illustrated by cell anergy and immune suppression.

Within clinical human studies, it has become evident that in association with specific parasites, including lymphatic filariasis, the body's T cells are unable to differentiate and proliferate, thus inhibiting any protective immune response. The studies of King et al. (1993), and Allen and Maizels (1996) suggest that this hyporesponsiveness seems to represent selective anergy of the Th1-type cells, in that Th2-type cytokine production is relatively undiminished. Borkow et al. (2000) researched signal transduction and anergy in association with helminth infections in Eastern African populations. Their subject group also included HIV-positive patients, and thus, they examined this diverse group's ability to handle parasitic load. Their research reveals that chronic immune activation that results from parasitic infection severely compromises one's ability to pro- tect oneself from HIV. Hyporesponsiveness and anergy were indicated by defective or lacking of early transmembrane signaling (phosphorylation and/or dephosphorylation of tyrosine kinases), lack of attenuated phosphorylation of downstream kinases, such as ERK and p38, and reduced proliferative capacity after antigen stimulation. These impairments of signal transduction pathways result in a biased Th2 response, and an inability to confer an adequate $\mathrm{Th} 1$ protective immune response against further infection, specifically HIV.

In addition to clinical trials, these theories have been explored within the murine model. Actor et al. (1993) examined the ability of Schistosome-infected BALB/c mice to clear vaccinia virus. Previous research revealed markedly low CD8+ CTL responses, and thus, Actor et al. (1993) hypothesized that this immune status would compromise the subject's ability to clear virus. Accordingly, their research revealed that delayed clearance is due to the concomitant downregulation in viralspecific Th1 cytokine and CD8 + CTL responses in the doubly infected animal. Thus, within both clinical and murine models, it has been demonstrated that a biased Th2 immune response and downregulation of CD8 + cells impair the subject's ability to clear additional virus. This is of particular relevance in the fight against HIV in the developing world, and the search for adequate and appropriate HIV and parasite vaccines.

\section{CONCLUSION}

In discussing parasitic disease, vaccine development and HIV infection, it becomes apparent that there is a strong correlation between poverty, unsanitary living conditions, parasitic infection, compromised, and biased immune systems, due to chronic activation, and fatal HIV infection. Many studies have demonstrated that the Th2 immunological response that results from chronic parasitic disease severely hinders the body's ability to clear additional virus, specifically HIV. Thus, development of vaccine models for both HIV and parasitic infection must consider and incorporate the immunology of other infections to adequately and appropriately address the health concerns of the developing world. Bloom argues that "the reality is millions of people are sick because they are poor, and poorer because they are sick" (Bloom, 1989). This statement reflects the complex web of social and economic interaction that must be examined to provide improved public health measures for the developing world. Vaccine development, parasitic disease, and HIV infection must be examined in correlation to the other health factors that impact specific populations.

\section{REFERENCES}

ACTOR, J.K., SHIRAI, M., KULLBERG, M.C., BULLER, M.M.L., SHER, A., and BERZOFSKY, J.A. (1993). Helminth infection results in decreased virus-specific CD8+ cytotoxic T-cell and Th1 cytokine responses as well as delayed virus clearance. Proc. Acad. Natl. Sci USA 90, 948-952.

ALLEN, J.E., and MAIZELS, R.M. (1996). Immunology of human helminth infection. Int. Arch. Allergy Immunol. 109, 3-10.

AMARA, R.R., VILLINGER, F., ALTMAN, J.D., LYDY, S.L., O'NEIL, S.P., STAPRANS, S.I., MONTEFIORI, D.C., XU, Y., HERNDON, J.G., WYATT, L.S., et al. (2002). Control of a mucosal 
challenge and prevention of AIDS by a multiprotein DNA/MVA vaccine. Vaccine 20, 1949-1955.

BELSHE, R.B., GORSE, G.J., MULLIGAN, M.J., EVANS, T.G., KEEFER, M.C., EXCLER, J.L., DULIEGE, A.M., TARTAGLIA, J., COX, W.I., MCNAMARA, J., et al. (1998). Induction if immune responses to HIB-1 by canarypox virus (ALVAC) HIV-1 and gp120 SF-2 recombinant vaccines in uninfected volunteers. AIDS 12, $2407-2415$.

BLOOM, B.R. (1989). Vaccines for the third world. Nature 342, $115-120$.

BORKOW, G., LENG, Q., WEISMAN, Z., STEIN, M., GALAI, N., KALINKOVICH, A., and BENTWICH, Z. (2000). Chronic immune activation associated with intestinal helminth infections results in impaired signal transduction and anergy. J. Clin. Invest. 106, $1053-1060$.

BORROW, P., LEWICKI, H., HAHN, B.H., SHAW, G.M., and OLDSTONE, M.B. (1994). Virus-specific $\mathrm{CD}^{+}$cytotoxic T-lymphocyte activity associated with control of viremia in primary human immunodeficiency virus type-1 infection. J. Virol. 68, 6103-6110.

BOT, A., HOLZ, A., CHRISTEN, U., WOLFE, T., TEMANN, A., FLAVELL, R., and VON HERRATH, M. (2000). Local IL-4 Expression in the lung reduces pulmonary influenza-virus specific secondary cytotoxic $\mathrm{T}$ cell responses. Virology 269, 66-77.

BOYER, J.D., COHEN, A.D., VOGT, S., SCHUMANN, K., NATH, B., AHN, L., LACY, K., BAGARAZZI, M.L., HIGGINS, T.J., BAINE, Y., et al. (2000). Vaccination of seronegative volunteers with a human immunodeficiency virus type 1 env/rev DNA vaccine induces antigen-specific proliferation and lymphocyte production of beta-chemokines. J. Infect. Dis. 181, 476-483.

BURES, R., GAITAN, A., ZHU, T., GRAZIOSI, C., MCGRATH, K.M., TARTAGLIA, J., CAUDRELIER, P., EL HABIB, R., KLEIN, M., LAZZARIN, A., et al. (2000). Immunization with recombinant canarypox vectors expressing membrane-anchored glycoprotein 120 followed by glycoprotein 160 boosting fails to generate antibodies that neutralize R5 primary isolates of human immunodeficiency virus type 1. AIDS Res. Hum. Retroviruses 16, 2019-2035.

CAO, Y., QIN, L., ZHANG, L., SAFRIT, J., and HO, D.D. (1995). Virologic and immunologic characterization of long-term survivors of human immunodeficiency virus type-1 infection. N. Engl. J. Med. 332, 201-208.

CAPRON, M., SPIEGELBERG, H.L., PRIN, L., BENNICH, H., BUTTERWORTH, A.E., PIERCE, R.J., QUAISSI, M.A., and CAPRON. A. (1984). Cytokine control of parasite-specific anergy in human lymphatic filariasis. Preferential induction of a regulatory $\mathrm{T}$ helper type 2 lymphocyte subset. J. Clin. Invest. 92, 1667-1673.

CDC (2001). www.dpd.cdc.gov/dpdx/html/para_health.htm

COCCHI, R., DEVICO, A.L., GARZINO-DEMO, A., ARYA, S.K., GALLO, R.C., and LUSSO, P. (1995). Identification of RANTES, MIP-1 alpha, MIP1-beta as the major HIV-1 suppressive factors produced by CD8 + T cell. Science 270, 1811-1815.

CULLEN, B., and GREENE, W.C. (1990). Functions of the auxiliary gene products of the human immunodeficiency virus type I. Virology 178, $1-5$.

CUNNINGHAM, C.K., WARA, D.W., KANG, M., FENTON, T., HAWKING, E., MCNARMARA, J., MOFENSON, L., DULIEGE, A.M., FRANCIS, D., MCFARLAND, E.J., et al., AND THE PEDIATRIC AIDS CLINICAL TRIALS GROUP 230 COLLABORATORS. (2001). Safety of 2 recombinant human immunodeficiency virus type 1 (HIV-1) envelope vaccines in neonates born to HIV-1infected women. Clin. Infect. Dis. 32, 801-807.

DE ANDRES, B., E. RAKASZ, M. HAGEN, M.L. MCCORMIK, A.L. MUELLER, D. ELLIOT, A. METWALI, M. SANDOR, B.E. BRITIGAN, J.V. WEINSTOCK, et al. (1997). Lack of Fc-epsilon receptors on murine eosinophils: Implications for the functional significance of elevated IgE and eosinophils in parasitic infections. Blood 89, 3826-3836.
DESSEIN, A.J., CHEVILlARD, C., MARQUET, S., HENRI, S., HILLAIRE, D., and DESSEIN, H. (2001). Genetics of parasitic infections. Drug Metab. Dispos. 29, 484-488.

FAN, L., and PEDEN, K. (1992). Cell-free transmission of Vif-mutants of HIV-1. Virology 190, 19-29.

FERRARI, G., HUMPHREY, W., MCELRATH, M.J., EXCLER, J.L., DULIEGE, A.M., CLEMENTS, M.L., COREY, L.C., BOLOGNESI, D.P., and WEINHOLD, K.J. (1997). Clade B-based HIV-1 vaccines elicit cross-clade cytotoxic $\mathrm{T}$ lymphocyte reactivities in uninfected volunteers. Proc. Natl. Acad. Sci. USA 94, 1396-1401.

FONTANET, A.L., SAHLU, T., DE WIT, T.R., MESSELE, T., MASHO, W., WOLDEMICHAEL, T., YENENEH, H., and COUTINHO, R.A. (2000). Epidemiology of infections with intestinal parasites and human immunodeficiency virus (HIV) among sugar-estate residents in Ethiopia. Ann. Trop. Med. Parasitol. 94, 269-278.

FRANCIS, D.P., HEYWARD, W.L., POPOVIC, V., OROZCOCRONON, P., ORELIND, K., GEE, C., HIRSCH, A., IPPOLITO, T., LUCK, A., LONGHI, M., et al. (2003). Candidate HIVAIDS vaccines: Lessons learned from the World's first phase III efficacy trials. AIDS 17, 147-156.

HEINZEL, F.P., SADICK, M.D., MUTHA, S.S., and LOCKSLEY, R.M. (1991). Production of interferon gamma, interleukin 2, interleukin 4 , and interleukin 10 by CD4+ lymphocytes in vivo during healing and progressive murine leishmaniasis. Proc. Natl. Acad. Sci. USA 88, 7011-7015.

HILLEMAN, M.R. (1999). Personal historical chronicle of six decades of basic and applied research in virology, immunology and vaccinology. Immunol. Rev. 170, 7-27.

HULSKOTTE, E.G., GERETTI, A.M., SIEBELINK, K.H., VAN AMERONGEN, G., CRANAGE, M.P., RUD, E.W., NORLEY, S.G., DE VRIES, P., and OSTERHAUS, A.D. (1995). Vaccine-induced virus neutralizing antibodies and cytotoxic $\mathrm{T}$ cells do not protect macaques from experimental infection with Simian immunodeficiency virus $\mathrm{SIV}_{\text {mac } 32 \mathrm{H}(\mathrm{J} 5)}$. J. Virol. 69, 6289-6296.

KESTLER, H., RINGLER, D.J., MORI, K., PANICALLI, D.L., SEHGAI, P.K., DANIEL, M.D., and DESROSIERS, R.C. (1991). Importance of the $n e f$ gene for maintenance of high virus loads and for the development of AIDS. Cell 65, 651-662.

KIM, S., IKEUCHI, K., BYRN, R., GROOPMAN, J., and BALTIMORE, D. (1989). Lack of negative influence on viral growth by the $n e f$ gene of human immunodeficiency virus type-1. Proc. Natl. Acad. Sci. USA 86, 9544-9548.

KING, C.L., MAHANTY, S., KUMARASWAMI, V., ABRAMS, J.S., REGUNATHAN, J., JAYARAMAN, K., OTTESEN, E.A., and NUTMAN, T.B. (1993). Cytokine control of parasite-specific anergy in human lymphatic filariasis. Preferential induction of a regulatory T helper type 2 lymphocyte subset. J. Clin. Invest. 92, 1667-1673. KLIMKAIT, T., STREBEL, K., HOGGAN, M.D., MARTIN, M.A., and ORENSTEIN, J.M. (1990). The human immunodeficiency virus type-1 specific protein $\mathrm{Vpu}$ is required for efficient virus mutation and release. J. Virol. 64, 621-629.

KWONG, P.D., WYATT, R., ROBINSON, J., SWEET, R.W., SODROSKI, J., and HENDRICKSON, W.A. (1998). Structure of an HIV gp120 envelope glycoprotein in complex with the CD4 receptor and a neutralizing antibody. Nature 393, 648-659.

LAMBERT, J.S., KEEFER, M., MULLIAN, M.J., SCHWARTZ, D., MESTECKY, J., WEINHOLD, K., SMITH, C., HSIEH, R., MOLDOVEANU, Z., FAST, P., et al. (2001). Phase I safety and immunogenicity trial of UBI microparticulate monovalent HIV-1 MN oral peptide immunogen with parenteral boost in HIV-1 seronegative human subjects. Vaccine 19, 3033-3042.

LEVY, D.N., REFAELI, Y., MACGREGOR, R.R., and WEINER, D.B. (1994a). Serum vpr regulates productive infection and latency of human immunodeficiency virus type-1. Proc. Natl. Acad. Sci. USA 91, 10873.

LEVY, D.N., REFAELI, Y., and WEINER, D.B. (1994b). Extracellu- 
lar vpr protein increases cellular permissiveness to HIV replication and reactivates virus from latency. J. Virol. 69, 1243-1252.

LEVY, D.N., FERNANDES, L.S., WILLIAMS, W.V., and WEINER, D.B. (1993). Induction of cell differentiation by human immunodeficiency virus-1 vpr. Cell 72, 541-550.

LEVY, J.A., BARKER, E., GUTHRIE, J., and ELBEIK, T. (1996). Plasma viral load CD4+ cell counts and HIV-1 production by cells. Science 270, 1811-1815.

MACGREGOR, R.R., BOYER, J.D., UGEN, K.E., GLUCKMAN, S.J., BAGARAZZI, M.L., CHATTERGOON, M.A., BAINE, Y., HIGGINS, T.J., CICCARELLI, R.B., CONEY, L.R., et al. (1998). First human trial of a DNA-based vaccine for treatment of human immunodeficiency virus type 1 infection: Safety and host response. J. Infect. Dis. 178(1), 92-100.

MACKEWICZ, C.E., ORTEGA, H.W., and LEVY, J.A. (1991). CD8 activity correlates with the clinical state of the infected individuals. J. Clin. Invest. 87, 1462-1466.

MCCORMACK, S., TILZEY, A., CARMICHAEL, A., GOTCH, F., KEPPLE, J., NEWBERRY, A., JONES, G., LISTER, S., BEDDOWS, S., CHEINGSONG, R., et al. (2000). A phase I trial in HIV negative healthy volunteers evaluating the effect of potent adjuvants on immunogenicity of a recombinant gp $120_{\mathrm{W} 6 \mathrm{ID}}$ derived from dual tropic R5X4 HIV-1 $1_{\mathrm{ACH} 320}$. Vaccine 18, 1166-1177.

MIGUELES, S.A., LABORICO, A.C., LESLEY, W., SABBAHHIAN, M.S., RABIN, R., HALLAHAN, C.W., VAN BAARLE, D., KOSTENSE, S., MIEDEMA, F., MCLAUGHLIN, M., et al. (2002). HIV-1 specific CD8 T cell proliferation is coupled to perforin expression and is maintained in nonprogressors. Nat. Immunol. 3, 1061-1068.

MOSMANN, T.R., and MOORE, K.W. (1991). IL-10 acts on the antigen-presenting cell to inhibit cytokine production by Th1 cells. J. Immunol. 146, 3444-3451.

NITAYAPHAN, S., KHAMBOONRUANG, C., SIRISOPHANA, N., MORGAN, P., CHIU, J., DULIEGE, A.M., CHUENCHITRA, C., SUPAPONGSE, T., RUNGRUENGTHANAKIT, K., DESOUZA, M., et al. (2000). A phase I/II trial of HIV SF2 gp120/MF59 vaccine in seronegative Thais. Vaccine 18, 1448-1455.

PEARCE, E.J., CASPAR, P., GRZYCH, J.M., LEWIS, F.A., and SHER, A. (1991). Downregulation of Th1 cytokine production accompanies induction of Th2 responses by a parasitic helminth, Schistosoma mansoni. J. Exp. Med. 173, 159-166.

PINTO, L., SUllivAN, J., BERZOFSKY, J.A., CLERICI, M., KESSLER, H.A., LANDAY, A.L., and SHEARER, G.M. (1995). Env-specific cytotoxic T lymphocyte responses in HIV seronegative health care workers occupationally exposed to HIV-contaminated body fluids. J. Clin. Invest. 96, 867-876.

QIU, J.T., SONG, R., DETTENHOFER, M., TIAN, C., AUGUST, T., FELBER, B.K., PAVLAKIS, G.N., and YU, X.F. (1999). Evaluation of novel human immunodeficiency virus type 1 Gag DNA vaccines for protein expression in mammalian cells and induction of immune responses. J. Virol. 73, 9145-9152.

ROSEN, C. (1991). Regulation of HIV gene expression by RNA-protein interaction. Trends Genet. 7, 9-14.

ROSENBERG, E.S., BILLINGS, J.M., CALIENDO, A.M., et al. (1997). Vigorous HIV-1 specific CD4 T cell responses associated with control of viremia. Science 278, 1447-1450.

ROSSI, P., MOSCHESE, V., and BROLIDEN, P. (1989). Presence of maternal antibodies to human immunodeficiency virus 1 envelope glycoprotein gp120 epitopes correlates with the uninfected status of children born to seropositive mothers. Proc. Natl. Acad. Sci. USA 86, 8055-8058.

ROWE, J., MACAUBAS, C., MONGER, T.M., HOLT, B.J., HARVEY, J., POOLMAN, J.T., SLY, P.D., and HOLT, P.G. (2000). Antigen-specific responses to diphtheria-tetanus-acellular pertussis vaccine in human infants are initially Th2 polarized. (2000). Infect. Immun. 68, 3873-3877.
ROWLAND-JONES, S., SUTTON, J., ARIYOSHI, K., DONG, T., GOTCH, F., MCADAM, S., WHITBY, D., SABALLY, S., ALLIMORE, A., CORRAH, T., et al. (1995). HIV-specific T-cells in HIV-exposed but uninfected Gambian women. Nat. Med. 1, 59-64.

ROWLAND-JONES, S., NIXON, D.F., and ALDHOUS, M.C. (1993). HIV-specific cytotoxic T-cell activity in an HIV-exposed but uninfected infant. Lancet 341, 860-861.

SABIN, E.A., ARAUJO, M.I., CARVALHO, E.M., and PEARCE, E.J. (1996). Impairment of tetanus toxoid-specific Th1-like immune responses in humans infected with Schistosoma mansoni. J. Infect. Dis. 173, 269-272.

SCOTT, P., SACKS, D., and SHER, A. (1983). Resistance to macrophage-mediated killing as a factor influencing the pathogenesis of chronic cutaneous leishmaniasis. J. Immunol. 131, 966-971.

SHER, A., GAZZINELLI, R.T., OSWALD, I.P., CLERICI, M., KULLBERG, M., PEARCE, E.J., BERZOFSKY, J.A., MOSMANN, T.R., JAMES, S.L., and MORSE, H.C., 3RD. (1992). Role of T-cell derived cytokines in the downregulation of immune responses in parasitic and retroviral infection. Immunol. Rev. 127, 183-204.

SHIVER, J.W., FU, T.M., CHEN, L., CASIMIRO, D.R., DAVIES, M.E., EVANS, R.K., ZHANG, Z.Q., SIMON, A.J., TRIGONA, W.L., DUBEY, S.A., et al. (2002). Replication-incompetent adenoviral vaccine vector elicits effective anti-immunodeficiency-virus immunity. Nature 415, 331-335.

SITZ, K.V., RATTO-KIM, S., HODGKINS, A.S., ROBB, M.L., and BIRX, D.L. (1999). Proliferative responses to human immunodeficiency virus type 1 (HIV-1) gp120 peptides in HIV-1-infected individuals immunized with HIV-1 rgp120 or rgp160 compared with nonimmunized and uninfected controls. J. Infect. Dis. 179, 817-824.

TOLEDO, H., BALY, A., CASTRO, O., RESIK, S., LAFERTE, J., ROLO, F., NAVEA, L., LOBAINA, L., CRUZ, O., MIGUEZ, J., et al. (2001). A phase I clinical trial of a multi-epitope polypeptide TAB9 combined with Montanide ISA 720 adjuvant in non-HIV-1 infected human volunteers. Vaccine. 19, 4328-4336.

UGEN, K.E., SRIKANTAN, V., GOEDERT, J.J., NELSON, R.P., WILLIAMS, W.V., and WEINER, D.B. (1997). Vertical transmission of Immunodeficiency Virus Type 1: Seroreactivity by maternal antibodies to the carboxy region of the gp41 envelope. J. Infect. Dis. 175, 63-69.

UGEN, K.E., GOEDERT, J.J., BOYER, J., REFAELI, Y., FRANK, I., WILLIAMS, W.V., WILLOUGHBY, A., LANDESMAN, S., RUBINSTEIN, A., KIEBER-EMMONS, T., et al. (1992). Vertical transmission of HIV infection. Reactivity of maternal sera with glycoprotein 120 and 41 peptides from HIV type 1 . J. Clin. Invest. 89, 1923-1930.

WEI, X., DECKER, J.M., WANG, S., HUI, H., KAPPES, J.C., WU, X., SALAZAR-GONZALEZ, J.F., SALAZAR, M.G., KILBY, J.M., et al. (2003). Antibody neutralization and escape by HIV-1. Nature. 422, 307-312.

WHO (2000). Infectious Diseases. Accessed April 2002. www.who.int/ health-topics/indindex.htm

WIWANITKIT, V. (2001). Intestinal parasitic infections in Thai HIVinfected patients with different immunity status. BMC Gastroenterol. 1, 1-5.

Address reprint requests to: Jean D. Boyer, Ph.D.

University of Pennsylvania 422 Curie Blvd, 505 SCL Philadelphia, PA 19104

E-mail: boyerj@mail.med.upem.edu 
This article has been cited by:

1. M. Ruber, A. Berg, C. Ekerfelt, G. Olaison, R. E. Andersson. 2006. Different cytokine profiles in patients with a history of gangrenous or phlegmonous appendicitis. Clinical and Experimental Immunology 143:1, 117-124. [CrossRef] 